\title{
Predicting Disease SPREAd IN GREATER YELLOWSTONE UNGULATES USING PARASITE DNA MARKERS
}

\author{
GORDON LUIKART + VANESSA EZENWA + MARTY KARDOS \\ DIVISION OF BIOLOGICAL SCIENCES \UNIVERSITY OF MONTANA $\downarrow$ MISSOULA
}

\author{
P.J. White NATIONAL PARK SERVICE \\ YELLOWSTONE NATIONAL PARK $\downarrow$ MAMMOTH \\ PAUl CROSS $\uparrow$ U.S. GeOlOGiCAl SuRVEY \\ NORTHERN ROCKY MOUNTAIN SCIENCE CENTER \ BOZEMAN
}

\begin{abstract}
$\downarrow$ INTRODUCTION
Infectious diseases are a serious threat to the viability of wildlife populations worldwide, including those in national parks and other protected areas where agricultural operations, development, and recreation are degrading and fragmenting habitat and increasing the potential for interactions between wildlife, domestic animals, and humans. The spread of infectious diseases and parasites is of particular concern in the greater Yellowstone area, which supports world-renowned herds of ungulates that provide significant visitor enjoyment and benefits to local economies through guiding and sport hunting. The high diversity, density, and co-mingling rates of ungulates in this area could facilitate the rapid emergence and spread of infectious diseases such as brucellosis, chronic wasting disease, and Johne's disease, with escalating disease threats to livestock and people along the public/private land interface.
\end{abstract}

A critical need is information on disease and parasite transmission pathways within and among species and through the greater Yellowstone area to help develop feasible strategies to minimize the adverse conservation,

economic, and social effects of diseases. We began addressing this need by identifying informative, polymorphic DNA markers from parasite propagules shed in ungulate feces that can be used to non-invasively identify, track, and map transmission routes across the greater Yellowstone area. Similar analyses of DNA markers from microparasites (e.g., viruses, bacteria) and macroparasites (e.g., helminths) in other areas have been used to determine the rates and routes of movement and disease spread by diverse host species such as cougars, salmon, and cattle (Blouin et al. 1995, Monis et al. 2005, Criscione et al. 2005, 2006; Biek et al. 2006).

The objectives of our study were to: 1) analyze the prevalence of parasites in elk and other ungulates inhabiting the northern and westcentral portions of Yellowstone National Park and Grand Teton National Park in Wyoming; 2) identify polymorphic nuclear and mtDNA loci for macro- and micro-parasites; and 3) estimate genetic differentiation and transmission rates within and between host species and populations from the three sampling locations. This information will help natural resource managers throughout the greater Yellowstone area to 
understand and map routes of spread of environmentally transmitted diseases such as brucellosis and chronic wasting disease, and predict the risks and routes of transmission.

\section{METHODS}

We collected 20 grams (e.g., 15-25 pellets) of fresh feces from elk, bighorn sheep, bison, pronghorn, and cattle from several geographic areas. Fecal samples were stored at $4^{\circ} \mathrm{C}$ for $<1$ month until parasites were isolated in the laboratory. A sub-sample of each fecal sample was also immediately placed in $95 \%$ ETOH and/or frozen for recovery of microparasites or direct PCR-based DNA analysis.

Helminth larvae were recovered from host fecal samples at the University of Montana using a modified Baermann method (Foryet 2001, Ezenwa 2004a). Parasite prevalence was estimated as the proportion of host individuals with the parasite (Ezenwa 2003, 2004b). DNA was isolated from individual larvae using commercial kits (e.g., DNAeasy tissue kits, Qiagen). Primers for PCR amplification and sequencing of mtDNA were available for Haemonchus and Dictyocaulus (Blouin 2002, Hoglund et al. 2006). Primers for microsatellite genotyping and PCR-sequencing of many nuclear genes were also available (e.g., ITS-1, ITS-2; Blouin 2002, Wimmer et al. 2004).

To study a microparasite, Brucella abortus, we sampled 77 bison from slaughter houses (over $1 / 2$ were seropositive for Brucella). We collaborated with other researchers and expect to obtain Brucella DNA isolates from an additional 50-100 bison, including animals migrating out of the northern and western boundaries of Yellowstone National Park. Also, we tested for Yersinia enterocolitica by culture from 30 bison feces from Grand Teton National Park. Isolation and culture of the bacteria was conducted in a commercial laboratory. DNA will be isolated from cultures (dead bacteria killed in $95 \% \mathrm{ETOH}$ ) or directly from fecal material using commercial kits (e.g., DNAeasy tissue kits, Qiagen). PCR primers for microsatellites and many nuclear genes are available for the bacteria species (e.g., Jourdan et al. 2000, Bricker and Ewaldt 2005, Sharma et al. 2006, Zheng et al. 2006).
DNA sequence analysis and estimation of polymorphism in each parasite species will be conducted using MEGA and Arlequin software (Luikart et al. 2001). Preliminary transmission rates will be estimated roughly as gene flow (i.e., migration) rates using population genetic distance statistics (e.g., $F_{\mathrm{ST}}$ ) and models of population structure (e.g., island and steppingstone models, using likelihood and Bayesian estimators; Beerli and Felsenstein 2001, Beerli 2006). Also, we will use assignment test approaches to directly identify recent transmissions without assumptions about population migration-mutation-drift equilibrium (e.g., Cornuet et al. 1999).

\section{$\downarrow \quad$ RESUlTS}

We sampled feces from bison, elk, bighorn, pronghorn, and/or cattle from Grand Teton National Park, the northern range of Yellowstone, along with 24 elk from Idaho on the Sand Creek wintering grounds. Prevalence of helminth parasites in each host species and each location are provided in Table 1.

We identified and optimized mitochondrial DNA primers for the ITS and NAD genes. We will soon PCR amplify and sequence ITS for species identification of approximately 8 nematodes from each host animal sampled to identify nematodes to species and to establish prevalence data. For one or two helminth species that are most prevalent, we will sequence NAD for approximately 30 worms per host species (elk, bison, pronghorn, and cattle) in each geographic location. This will allow for preliminary estimates of parasite population genetic structure (and transmission rates) within verses between host species and geographic locations.

We developed a quantitative real-time PCR test for Brucella DNA to help identify infected bison and elk. This test will be applied to feces, urine, blood and tissue. We also are genotyping 10 HOOF-print VNTR (variable number of tandem repeat or microsatellites) in collaboration with researchers at the National Animal Disease Center in Ames, Iowa (G. Luikart, manuscript in preparation). This will allow for estimation of transmission rates within and between elk and bison populations. 


\begin{tabular}{|c|c|c|c|c|c|}
\hline Location & $\begin{array}{c}\text { No. } \\
\text { fecal } \\
\text { samples } \\
\end{array}$ & Host species & Protostrongylus & Dictyocaulus & $\begin{array}{l}\text { G.I. } \\
\text { nematodes }\end{array}$ \\
\hline \multirow{4}{*}{$\begin{array}{c}\text { Grand Teton } \\
\text { NP }\end{array}$} & 38 & elk & 0 & 0.22 & $0.1^{*}$ \\
\hline & 32 & bison & 0.08 & 0.28 & 0.44 \\
\hline & 19 & $\begin{array}{l}\text { bighorn } \\
\text { sheep }\end{array}$ & 1.0 & 0.05 & 1.0 \\
\hline & 35 & $\begin{array}{l}\text { cattle (Pinto } \\
\text { Ranch) }\end{array}$ & 0.03 & 0 & 0.15 \\
\hline \multirow{3}{*}{$\begin{array}{c}\text { Yellowstone } \\
\text { NP }\end{array}$} & 20 & elk & likely zero & 0.56 & 0.75 \\
\hline & 15 & pronghorn & \multicolumn{2}{|c|}{0.87 (genus uncertain) } & 0.8 \\
\hline & 41 & bison & 0.13 & 0.1 & 0.76 \\
\hline \multirow{2}{*}{$\begin{array}{l}\text { Northern } \\
\text { Wyoming } \\
\text { (outside YNP } \\
\text { and GTNP) }\end{array}$} & 22 & cattle & \multicolumn{2}{|c|}{0.09 (genus not certain) } & 0.53 \\
\hline & 13 & pronghorn & \multicolumn{2}{|c|}{0.92 (genus uncertain) } & 0.91 \\
\hline $\begin{array}{l}\text { Bench/Jewett } \\
\text { Feed Grounds }\end{array}$ & 20 & elk & likely zero & 0.58 & 0.08 \\
\hline
\end{tabular}

No Yersinia positives were identified in 30 bison feces from Grand Teton National Park. We currently are testing 120 more fecal samples from bison on their summer range and those consigned to slaughter from Yellowstone National Park, as well as samples from bison in Grand Teton National Park during winter. We will be testing these fecal samples, plus many fecal samples from elk, for Yersinia enterocolitica (strain 0:9) by PCR directly from feces and lymph node DNA isolates. Once PCR or culture identifies Yersinina, we intend to sequence a few gene fragments to identify polymorphisms for studying transmission, depending on funding availability.

\section{$\downarrow$ Literature Cited}

Beerli, P. 2006. Comparison of Bayesian and maximum likelihood inference of population genetic parameters. Bioinformatics 22:341-345.
Beerli, P., and J. Felsenstein. 2001. Maximum likelihood estimation of a migration matrix and effective population sizes in $\mathrm{n}$ subpopulations using a coalescent approach. Proceedings of the National Academy of Sciences USA 98:45634568 .

Biek, R, A.J. Drummond, and M. Poss. 2006. A virus reveals population structure and recent demographic history of its carnivore host. Science 311:538-541.

Blouin, M.S. 2002. Molecular prospecting for cryptic species of nematodes: mitochondrial DNA versus internal transcribed spacer. International Journal for Parasitology 32:527-531.

Blouin, M.S., C.A. Yowell, C.H. Courtney, and J.B. Dame. 1995. Host movement and the genetic structure of populations of parasitic nematodes. Genetics 141:1007-1014. 
Bricker, B.J., and D.R. Ewalt. 2005. Evaluation of the hoof-print assay for typing Brucella abortus strains isolated from cattle in the United States: results with four performance criteria. BMC Microbiology 5:37.

Cornuet J.M., S. Piry, G. Luikart, A. Estoup, and M. Solignac. 1999. New methods employing multilocus genotypes for selecting or excluding populations as origins of individuals. Genetics 153:1989-2000.

Criscione, C.D., R. Poulin and M.S. Blouin. 2005. Molecular ecology of parasites: elucidating ecological and microevolutionary processes. Molecular Ecology 14:2247-2257.

Criscione, C.D., B. Cooper, and M.S. Blouin. 2006. Parasite genotypes identify source populations of migratory fish more accurately than fish genotypes. Ecology 87:823-828.

Ezenwa, V.O. 2004a. Selective defecation and selective foraging: antiparasite behavior in wild ungulates? Ethology 110:851-862.

Ezenwa, V.O. 2004b. Host social behavior and parasitic infection: a multifactorial approach. Behavioral Ecology 15:446454.

Foryet, W.J. 2001. Veterinary Parasitology Reference Manual, 5th Edition. Iowa State University Press, Ames.

Hoglund J., D.A. Morrison, J.G.Mattsson, A. Engstrom. 2006. Population genetics of the bovine/cattle lungworm (Dictyocaulus viviparus) based on mtDNA and AFLP marker techniques. Parasitology 133:89-99.
Jourdan A.D., S.C. Johnson, and I.V. Wesley. 2000. Development of a fluorogenic 5' nuclease PCR assay for detection of the ail gene of pathogenic Yersinia enterocolitica. Applied Environmental Microbiology 66:3750-3755.

Luikart G., L. Gielly, L. Excoffier, J.D. Vigne, J. Bouvet, and P. Taberlet. 2001. Multiple maternal origins and weak phylogeographic structure in domestic goats. Proceedings of the National Academy of Sciences USA 98:59275930.

Monis, P.T., S. Giglio, A.R. Keegan, and R.C. Andrew Thompson. 2005. Emerging technologies for the detection and genetic characterization of protozoan parasites. Trends in Parasitology $21: 340-346$

Sharma, S., S. Mittal, S. Mallik, and J.S. Virdi. 2006. Molecular characterization of beta-lactamase genes blaA and blaB of Yersinia enterocolitica biovar 1A. FEMS Microbiology Letters 257:319327.

Wimmer B, B.H. Craig, J.G. Pilkington, and J.M. Pemberton. 2004. Non-invasive assessment of parasitic nematode species diversity in wild Soay sheep using molecular markers. International Journal of Parasitology 34:625-631.

Zheng, H.X., M.J. Zhang, Y. Sun, and B. Jiang. 2006. Detection of Yersinia enterocolitica in diarrhea stool by realtime PCR. Zhonghua Yi Xue Za Zhi. $86: 2281-2284$. 